\title{
Dampak Penambangan Pasir Besi Di Desa Bandungharjo, Banyumanis Dan Ujungwatu Kabupaten Jepara Menurut UU No. 32 Tahun 2009 Tentang Perlindungan Dan Pengelolaan Lingkungan Hidup Suroto ${ }^{*}$, Gunarto ${ }^{* *}$
}

* Mahasiswa Program Magister (S2) Ilmu Hukum Fakultas Hukum UNISSULA Semarang, email :
murodtop76@gmail.com
** Guru Besar Fakultas Hukum UNISSULA ABSTRAK

Kebijakan penambangan pasir besi merupakan sebuah kebijakan yang menuai konflik. Ada perbedaan kepentingan antara pemerintah dengan masyarakat. Seperti yang terjadi di Desa Bandungharjo Kabupaten Jepara. Pemerintah mewacanakan sebuah kebijakan yang menuai konflik, yaitu pembangunan area transmigrasi Ring I di lahan pesisir, tepatnya di Pesisir Desa Bandungharjo Kecamatan Donorojo. masyarakat yang menolak kebijakan kemudian membentuk sebuah kelompok, yaitu Paguyupan Petani Lahan Pantai (PPLP). Pemerintah telah mencoba untuk melakukan pendekatan dengan kelompok ini. Selain melakukan pendekatan kepada kelompok yang kontra, pemerintah juga melakukan pendekatan pada kelompok yang pro. Penelitian ini menggunakan jenis kualitatif dengan metode studi kasus. Pengumpulan data dilakukan dengan wawancara serta observasi non-partisipan untuk data primer dan melalui pelacakan dokumen atau literatur pendukung untuk mendapatkan data sekunder. Kedua data ini digunakan untuk saling meng-cross cheek agar hasilnya lebih valid. Penelitian ini menemukan bahwa konflik kebijakan penambangan pasir besi terjadi karena adanya perbedaan persepsi antara pemerintah dengan masyarakat atas pengelolaan tanah. pemerintah berusaha untuk memaksa masyarakat, sementara masyarakat berusaha untuk melawan pemerintah. Keadaan terebut menimbulkan konflik vertikal, antara pemerintah dengan masyarakat. Dalam perkembangannya, dinamika konflik terjadi ketika pemerintah berusaha untuk menyelesaikan konflik tersebut. Pemerintah tidak menggunakan cara yang demokratis melainkan tindak kekerasan baik fisik atau pun non fisik dilakukan pemerintah untuk meredam suara masyarakat yang kontra terhadap kebijakan. Dalam melakukan teror dan intimidasi, pemerintah juga melibatkan aktor lain seperti birokrasi maupun investor. Sementara itu, untuk kelompok yang pro, pemerintah melakukan pendekatan dengan memberikan informasi maupun sosialisai. Implikasi yang timbul kemudian adalah muncul konflik yang lebih luas, yaitu konflik antara masyarakat yang pro dan yang kontra terhadap kebijakan.

Keyword: $\quad$ Pertambangan pasir, konflik sosial, dampak kebijakan, UU No. 32 Tahun 2009.

\section{ABSTRACT}

The iron sand mining policy is a conflicting policy. There is a difference of interest between government and society. As happened in the Bandungharjo Village of Jepara Regency. The Government discourses a policy that reap the conflict, namely the development of transmigration area Ring I in coastal areas, precisely in the Coastal of Bandungharjo Village in Donorojo District. People who rejected the policy then formed a group, namely Paguyupan Petani Lahan Pantai (PPLP). The government has tried to approach this group. In addition to approaching the counter-group, the government also approaches pro-groups.

This is qualitative research with case study method. Data collection was done by interviewing and nonparticipant observation for primary data and by tracking documents or supporting literature to obtain secondary data. Both of these data are used to cross-check each other to make the result more valid. This study finds that iron sand mining policy conflict occurs because of differences in perception between government and society over land management. The government try to force the people, 
while the public try to fight the government. This state of affairs leads to vertical conflict, between government and society. In its development, conflict dynamics occurs when the government seeks to resolve the conflict. The government does not use democratic way to solve the problems, but acts of violence, whether physical or non-physical, is carried out by the government to decrease the voice of the people who are against the policy. In conducting terror and intimidation, the government also involves other actors such as bureaucracy as well as investors. Meanwhile, for pro groups, the government approaches by providing information and socialization. The subsequent implication is that there is a wider conflict, the conflict between the pro and the counter to the policy.

Keyword: Sand mining, social conflict, policy impact.

\section{PENDAHULUAN}

Indonesia merupakan negara yang kaya akan sumber daya alam, salah satunya adalah sumber daya mineral yang lebih banyak dipergunakan sebagai bahan baku industri. Pemerintah Republik Indonesia sendiri membagi bahan galian menjadi 3 golongan, antara lain: Bahan galian golongan $A$ (bahan galian strategis), Bahan galian golongan B (bahan galian vital), bahan galian golongan C (bahan galian non strategis dan non vital. Penggolongan tersebut membuktikan bahwa begitu banyak sumber daya mineral yang ada di Indonesia.

Pasir besi sebagai salah satu bahan baku utama dalam industri baja dan industri alat berat lainnya di Indonesia, keberadaannya memiliki peranan yang sangat penting. Berbagai permintaan dari berbagai pihak meningkat. Salah satu daerah yang memiliki potensi tersebut adalah pesisir pantai Desa Bandungharjo, desa Bayumanis dan Desa Ujungwatu Kecamatan Donorojo Kabupaten Jepara. Daerahdaerah tersebut kaya akan pasir besi tersebut, salah satu yang menjadi bahan penelitian ini adalah pertambangan pasir besi yang ada di Desa Bandungharjo, desa Bayumanis dan Desa Ujungwatu Kecamatan Donorojo Kabupaten Jepara. Dimana disana terdapat pertambangan pasir besi yang merupakan daya serap tenaga kerja bagi masyarakat, tetapi disamping itu ada banyak dampak pula yang dirasakan oleh masyarakat hal tersebut masih menjadi kontroversi ditengah-tengah masyarakat luas dan diharapkan ada penyelesaian untuk mengatasinya.

Di tengah konflik antara masyarakat dan pemerintah mengenai pertambangan pasir di di Desa Bandungharjo, desa Bayumanis dan Desa Ujungwatu Kecamatan Donorojo Kabupaten Jepara, UU No. 32 Tahun 2009 Tentang Perlindungan dan Pengelolaan Lingkungan Hidup menjadi acuan bagaimana melihat penyelesaian konflik yang terjadi mengenai pemanfaatan lingkungan tersebut.

Pertambangan adalah rangkaian kegiatan dalam rangka upaya pencarian, penambangan (penggalian), pengolahan, pemanfaatan dan penjualan bahan galian (mineral, batubara, panas bumi, migas, dll). Selanjutnya, pengertian pertambangan pasir besi rangkaian kegiatan dalam rangka upaya pencarian, penambangan (penggalian), pengolahan, pemanfaatan dan penjualan bahan galian c yaitu pasir besi.

Sedangkan lingkungan (enviroment atau habitat) adalah suatu sistem yang kompleks dimana berbagai faktor berpengaruh timbal-balik satu sama lain dan dengan masyarakat tumbuh-tumbuhan.

Dalam pertambangan pasir besi banyak dampak yang diakibatkan, baik positif maupun negatif. Dampak positifnya dari pertambangan pasir yaitu menyerap tenaga kerja di sekitar lingkungan pertambangan. Sedangkan dampak negatifnya adalah rusaknya lingkungan sekitar pertambangan.

Menurut Undang-Undang Lingkungan Hidup No. 23 Tahun 1997 Pasal 1 yang kemudian disempurnakan oleh Undang-Undang No. 32 Tahun 2009, keduanya mendefinisikan pengertian lingkungan hidup sebagai berikut: "Lingkungan hidup adalah kesatuan ruang dengan semua benda, 
daya, keadaan, dan makhluk hidup termasuk manusia dan perilakunya, yang mempengaruhi perikehidupan dan kesejahteraan manusia serta makhluk hidup lain."

Selanjutnya dalam UU No. 32 Tahun 2009, pengertian lingkungan hidup diperjelas lagi dengan pasal tentang pengendalian lingkungan hidup sebagai berikut: "Pengedalian pencemaran dan/atau kerusakan lingkungan hidup dilaksanakan dalam rangka pelestarian fungsi lingkungan hidup. Pengedalian pecemaran dan/atau kerusakan lingkungan hidup ini terdiri dari 3 hal yaitu: pencegahan, penanggulangan dan pemulihan lingkungan hidup dengan menerapkan berbagai instrument yaitu: Kajian lingkungan hidup straegis (KLHS); Tata ruang; Baku mutu lingkungan hidup; Kreteria baku mutu kerusakan lingkungan hidup; Amdal; UKL-UPL; perizinan; instrument ekonomi lingkungan hidup; peraturan perundang-undangan berbasis lingkungan hidup; anggaran berbasis lingkungan hidup; Analisis resiko lingkungan hidup; audit lingkungan hidup, dan instrument lain sesuai dengan kebutuhan dan/atau perkembangan ilmu pengetahuan."

\section{Metode Penelitian}

Penelitian ini merupakan penelitian deskriptif, yaitu penelitian yang dilakukan terhadap variabel mandiri tanpa membuat perbandingan atau menghubungkan dengan variabel lama. ${ }^{1}$ Sedangkan pendekatan penelitian yang digunakan adalah Yuridis Sosiologis yang menjelaskan mengenai fungsi hukum sebagai alat untuk merekayasa masyarakat dalam proses pembangunan (law as a tool of social engineering). ${ }^{2}$

Untuk metode penelitian menggunakan kualitatif dengan metode studi kasus. Pengumpulan data dilakukan dengan wawancara serta observasi non-partisipan untuk data primer dan melalui pelacakan dokumen atau literatur pendukung untuk mendapatkan data sekunder. Kedua data ini digunakan untuk saling meng-cross cheek agar hasilnya lebih valid.

\section{HASIL DAN PEMBAHASAN}

Di Wilayah Kabupaten Jepara terdapat beberapa lokasi Pasir besi antara lain:

1. Kecamatan Kembang di Desa Balong,

2. Kecamatan Keling di Desa Bumiharjo,

3. Kecamatan Donorojo di Desa Bandungharjo, Desa Banyumanis dan Desa Ujung Watu.

Adapun Perusahaan yang telah memiliki ijin produksi untuk melakukan Penambangan Pasir Besi yaitu di Kabupaten Jepara, antara lain:

1. PT. PASIR RANTAI MAS.

Lokasi tambang seluas $200 \mathrm{Ha}$ yang terletak di desa Bumiharjo Kec. Keling dan desa Balong Kec. Kembang, Jepara sesuai dengan surat ijin usaha penambangan (IUP) Nomor: 540/003/IUPOP/BPPT/VIII/2010 tanggal 12 Agustus 2010, yang berlaku sampai dengan 12 Oktober 2026, atas nama Daniel Hanawi/ Arif yang dikeluarkan oleh BPPT Kab. Jepara. Sampai saat ini PT PASIR RANTAI MAS masih melakukan aktifitas penambangan pasir besi sesuai dengan lokasi tambang yang tertera dalam perijinan yang dimiliki oleh perusahaan.

2. CV. GUCI MAS NUSANTARA

CV. GUCI MAS NUSANTARA adalah milik Sdr. H. Pawoko, alamat Jl. Mangun Sarkoro No.68 B Jepara, yang bergerak dibidang Pertambangan Pasir Besi berlokasi di Ds. Bandungharjo Kec. Donorojo Kab. Jepara seluas $14 \mathrm{Ha}$ dan telah memiliki ijin menambang (produksi) sesuai dengan Nomor : 540/ 002/ IUP- OP/ BPPT/ IV/ 2010 tanggal 20 April 2010 yang berlaku sampai dengan 26

\footnotetext{
${ }^{1}$ Sugiono. Metode penelitian adminitratif. 1998 hal 6

${ }^{2}$ Gunarto dalam Soemitro, Metode Penelitian Hukum. 1983.
} 
September 2013, ijin di keluarkan oleh BPMPPT (Badan Penanaman Modal Pelayanan Perijinan Terpadu).

Proses pengeluaran ijin tambang untuk CV tersebut, pertama kali pada tahun 2008 dengan luas lokasi tambang 1,3 Ha, selanjutnya pada tanggal 20 April 2010 penyesuaian ijin kuasa pertambangan menjadi ijin usaha pertambangan operasi produksi dengan luas lokasi tambang 14 Ha yang berlaku hingga 26 September 2013 sesuai dengan proses ijin pertama (5 Tahun). ${ }^{3}$

Selama Tahun 2008 sampai dengan Tahun 2011 belum terdapat aktivitas pertambangan yang dilakukan oleh CV. GUCI MAS NUSANTARA. Desember 2011, aktifitas penambangan pertama kali dilaksanakan. Adanya penambangan tersebut membuat warga sekitar lokasi merasa gelisah akan dampak dari penambangan Pasir Besi dimana para warga tinggal. Kemudian perwakilan warga mendatangi BLH (Badan Lingkungan Hidup) Kab. Jepara untuk beraudensi yang diterima oleh Bapak Ahmad Junaidi (Kepala BLH), didapat keterangan dari Kepala BLH bahwa ljin penambangan sudah diperoleh pihak CV. GUCI MAS NUSANTARA Tahun 2008 yang dikeluarkan oleh Pemda Kab. Jepara lewat Dinas BPPT dan dalam Audensi tersebut warga tidak puas karena warga sendiri tidak mengetahui ijin yang di miliki oleh CV. GMN dan sebelumnya tidak ada sosialisasi, persetujuan maupun pemberitahuan kepada masyarakat.

Pada tanggal 21 Pebruari 2012 warga beraudensi dengan Bupati Jepara, yang diwakili oleh SKPD terkait (BLH, Dinas Perindustrian, BPPT) di ruang Setda Kab. Jepara yang dihadiri perwakilan CV. GMN, dan dalam audensi tersebut dicapai kesepakatan supaya CV. GMN mau menyelenggarakan sosialisasi dan membicarakan rencananya kepada warga yang terkena dampak penambangan secara langsung.

Pada tanggal 29 Pebruari 2012 dilaksanakan acara sosialisasi rencana penambangan oleh CV. GMN di ruang pertemuan TPI Mulyorejo Ds. Bandungharjo Kec. Donorojo Kab. Jepara, hadir dalam acara tersebut perwakilan dari CV. GMN, DANRAMIL Keling, Camat Donorojo dan beberapa anggota Polsek Donorojo. Pada kesempatan tersebut CV. GMN memaparkan bahwa rencana penambangan Pasir besi di lokasi Ds. Bandungharjo dalam waktu dekat, camat dan Danramil meminta dukungan dari warga karena CV. GMN telah memiliki ijin produksi. Akan tetapi warga merasa keberatan dan menolak penambangan Pasir besi oleh CV. GMN karena akan mengancam kelangsungan hidup masyarakat yang berdekatan dengan lokasi tambang, yang mayoritas sebagai nelayan dan petani. Dengan adanya penolakan warga pertemuan tersebut tidak mencapai kesepakatan karena tidak terdapat titik temu kedua belah pihak.

Pada tanggal 09 Maret 2012 perwakilan warga mendatangi rumah petinggi Ds. Bandungharjo untuk memberikan surat penolakan atas rencana penambangan pasir oleh CV. GMN. Pada tanggal 12 Maret 2012 bego/eskavator (alat berat) sudah bekerja lagi melakukan pengerukan/ penambangan di lokasi, pengerukan dapat dihentikan secara baik- baik oleh warga dan warga mengatakan kalau belum ada musyawarah dan kesepakatan dengan petani pemilik lahan dari pihak CV. GMN tidak boleh beroperasi.

3. PT. ALAM MINERAL LESTARI

Lokasi tambang PT. ALAM MINERAL LESTARI seluas 200 Ha yang terletak di desa Bandungharjo, Banyumanis, dan Ujung Watu Kec. Donorojo, Jepara sesuai dengan Surat ljin Usaha Penambangan (IUP) Nomor : 540 /002 /IUP-OP/BPMPPT/ IV/2012 tanggal 16 April 2012, yang berlaku sampai dengan 15 April 2022, atas nama Seno Hanawi (keluarga Daniel Hanawi) / Prasojo Budiman alias Jojo yang dikeluarkan oleh BPMPPT Kab. Jepara.

\footnotetext{
${ }^{3}$ Kantor BPPT Kab. Jepara.
} 
Selama proses pengajuan ijin penambangan ke BPMPPT (Badan Penanaman Modal dan Pelayanan Perijinan Terpadu) dari pihak PT. AML telah melaksanakan sosialisasi kepada masyarakat lokasi tambang Pasir Besi yang terdiri dari: Desa Bandungharjo, Desa Banyumanis dan Desa Ujung Watu Kecamatan Donorojo Kabupaten Jepara.

Bahwa pada hari Rabu tanggal 21 September 2011 pukul 10.00 s/d 12.00 wib di RM. Maribu Jepara telah berlangsung Rapat Komisi KA AMDAL yang dipimpin oleh Ahmad Junaidi (Kepala Dinas BLH Kab. Jepara) tentang Rencana Kegiatan Penambangan Pasir Besi di Desa Bandungharjo, Desa Banyumanis dan Desa Ujung Watu Kecamatan Donorojo Kabupaten Jepara oleh PT. ALAM MINERAL LESTARI pada kesempatan tersebut hadir tim AMDAL masing - masing dari :

1. Tim Teknis AMDAL dari PT. ALAM MINERAL LESTARI

2. BLH (Badan Lingkungan Hidup) Prov. Jateng dan Kab. Jepara.

3. Unsur Perguruan Tinggi dari UNDIP Semarang.

4. Perhutani Wilayah Kab. Pati

5. Muspika Kecamatan Donorojo

6. Petinggi Desa Banyumanis, Bandungharjo dan Desa Ujung Watu

7. LSM dan Wakil Masyarakat yang berada di lokasi tambang.

Dalam rapat tersebut dicapai kesepakatan beberapa hal dalam kerangka dokumen AMDAL yaitu :

1. Format penyusunan KA AMDAL harus sesuai dengan Peraturan Menteri Lingkungan Hidup Nomor 8 tahun 2006.

2. Batas lahan penambangan dan status lahan harus jelas secara detail / fokus kegiatan

3. Kelengkapan administrasi dan teknis harus dipenuhi seperti peta batas wilayah, peta toporafi dan peta alur.

4. Pelaksanakan penambangan harus jelas setiap tahap penambangan, khusus untuk tahap pasca operasional agar dibedakan secara tegas setelah tahapan penambangan selesai.

5. Tata ruang agar disesuaikan dengan rencana giat tata ruang menyangkut peruntukan tata ruang.

Dalam kurun waktu beberapa tahun ini masyarakat di Bandungharjo dan Ujungwatu khususnya di daerah sekitar penambangan bijih besi banyak memberikan respon terhadap aktivitas penambangan tersebut, baik respon positif maupun respon negatif. Kebanyakan diantaranya memberikan respon negatif atau kurang setuju dengan kegiatan penambangan tersebut karena dirasakan merusak lingkungan.

Dampak positif yang dirasakan yaitu salah satunya adalah dapat Menyerap tenaga kerja, Masyarakat disekitar penambangan memang merasa terbantu dengan adanya penambangan bijih ini karena mereka bisa ikut bekerja menjadi buruh disana, bagi sebagian masyarakat memang menyadarinya karena pertambangan tersebut memberikan sedikit keringanan beban. Disamping itu tambang bijih besi memiliki daya tarik tersendiri keberadaannya, dimana pada awal keberadaannya menjadi daya tarik bagi Cikawung untuk menarik masyarakat luar, karena masyarakat lain ingin mengetahui keberadaan dan keadaan tambang besi tersebut.

Sementara itu dampak yang paling negatif adalah:

1. Merusak pantai dan vegetasinya. Keadaan pantai sebelum adanya penambangan bijih besi di daerah sekitar penambangan pasir menunjukan kondisi pantai yang begitu alami dan indah , berbagai jenis vegetasi pantai tumbuh di sepanjang jalur pantai. Tapi kini sudah mulai tergerus oleh kegiatan penambangan.

2. Rusaknya jalan raya. Kerusakan yang paling parah akibat dari kegiatan pertambangan bijih besi ini adalah rusaknya jalan raya yang menjadi penghubung jalur pantai utara, keadaan ini menyebabkan 
arus transportasi barang dan manusia menjadi terhambat. Sejak awal kondisi jalan raya yang menjadi penghubung sudah rusak dan kini diperparah dengan adanya kegiatan pengangkutan bijih besi, dengan hilir mudiknya truk-truk besar yang mengangkut bijih besi tersebut. Masyarakat menyayangkan keadaan tersebut dimana keadaan ini membuat mereka tidak nyaman.

3. Tingkat polusi udara yang makin meningkat. Hal ini disebabkan oleh hilir mudiknya truk-truk pengangkut bijih besi yang melintas, yang membawa bijih tersebut dari daerah ke daerah lain, khususnya daerah desa tersebut dan sekitarnya.

4. Rusaknya area persawahan atau pertanian warga. Lahan pertanian warga menjadi rusak akibat kegiatan pertambangan ini, diduga aliran air yang ke persawahan menjadi terganggu, akibatnya sawah warga menjadi cepat kering. Disamping itu area perkebunan yang tadinya rindang oleh kelapa kini menjadi tandus dan kering.

Pertambangan pasir di Kabupaten Jepara juga tidak lepas dari permasalahan munculnya konflik. Konflik sosial adalah salah satu bentuk interaksi sosial antara satu pihak dengan pihak lain didalam masyarakat yang ditandai dengan adanya sikap saling mengancam, menekan, hingga saling menghancurkan. Konflik sosial sesungguhnya merupakan suatu proses bertemunya dua pihak atau lebih yang mempunnyai kepentingan yang relative sama terhadap hal yang sifatnya terbatas. Dengan demikian, terjadilah persaingan hingga menimbulkan suatu benturan-benturan fisik baik dalam skala kecil maupun dalam skala besar. Dimana kondisi ini menjadi perhatian masyarakat karena dapat merugikan, mengancam, menggemparkan, menyebabkan ketakutan atau berpotensi menyebabkan terjadinya gangguan ketertiban dan keamanan dalam masyarakat (khususnya kejadian-kejadian yang tampaknya terpisah tetapi mempunyai kesamaan-kesamaan tentang pola, waktu, korban dan atau lokasi geografis).

Warga dengan pengusaha tambang di suatu daerah bisa mengundang konflik jika tidak dilandasi dengan suatu kebijakan yang sama-sama diterima kedua belah pihak. Ada beberapa faktor yang dapat menyebabkan konflik antara warga dan pengelola tambang, diantaranya faktor ekonomi, jalur pelayaran, sengketa lahan, penggunaan kekerasan dalam penyelesaian masalah dan perspektif negatif masyarakat terhadap aktifitas penambangan.

Adapun pihak yang terkait dengan dunia pertambangan itu adalah pemerintah, termasuk pemerintah daerah, legislatif dan pengusaha. Pemerintah dalam hal ini adalah pihak yang berperan dalam pemberian ijin pertambangan, sementara dewan melakukan kontrol pengawasan melalui komisi terkait, dan pengusaha pertambangan adalah pelaku dalam bisnis pertambangan itu sendiri.

Konflik sosial tidak akan muncul akibat pertambangan bila semua peraturan hukum dijalankan dengan sebaik-baiknya, misalnya dalam pengurusan dokumen analisa dampak lingkungan (Amdal). Tidak jarang ada pengusaha tertentu yang tidak membuat Amdal dengan sebenar-benarnya, hal inilah yang justru menjadi pemicu konflik dikemudian hari.

Untuk menghindari terulangnya kembali konflik sengketa lahan tambang di berbagai wilayah Indonesia yang menimbulkan korban jiwa maupun kerugian material Pemerintah Kabupaten Jepara mengadakan pendekatan permasalahan Kamtibmas dan kejahatan untuk mencari pemecahan suatu permasalahan melalui upaya memahami masalah, analisis masalah, mengusulkan alternatif-alternatif solusi yang tepat dalam rangka menciptakan rasa aman, tentram (tidak hanya berdasarkan penegakkan hukum), melakukan evaluasi serta evaluasi ulang terhadap efektifitas solusi yang dipilih.

Berbagai upaya untuk mewujudkan pemeliharaan Kamtibmas, perlindungan, pengayoman dan pelayanan kepada masyarakat, serta penegakan hukum terus dilakukan sehingga masyarakat merasa puas dan memberikan apresiasi yang baik atas keberhasilan pelaksanaan tugas Polri di wilayah Polres Jepara. Keberhasilan tersebut tidak terlepas dari kerja keras seluruh anggota Polri dan dukungan kuat dari Pemerintah dan masyarakat. 
Dalam menangani konflik telah dilakukan berbagai upaya, antara lain memberikan kesempatan kepada para pengusaha penambangan pasir besi untuk memperbaiki presentasi yang akan dipaparkan agar dapat meyakinkan kepada FORKOPINDA untuk merekomendasikan kegiatan penambangan dapat dijalankan atau dilanjutkan, melalui pemaparan kegiatan CSR riil yang telah dilakukan maupun yang akan dilaksanakan kedepan disertai bukti pendukung dan pola pemberdayaan masyarakat melalui kerjasama kegiatan penambangan. Terkait dengan poin diatas maka perlu dibentuk tim pengawas terhadap CSR riil yang telah diberikan agar dapat dimanfaatkan secara maksimal.

Bahwa CSR yang sudah dilaksanakan sudah mendapatkan apresiasi oleh Pemerintah Kabupaten Jepara. Bahwa pengerjaan penambangan pasir besi diharapkan dapat melibatkan/ dikerjasamakan masyarakat / kelompok masyarakat sekitar dengan cara dilakukan pendampingan, pengawasan, dipinjami alat dan hasil tambang dibeli dengan harga yang pantas sesuai kesepakatan.

Perlunya sosialisasi dan pendekatan kepada warga di sekitar penambangan pasir besi agar kegiatan penambangan dapat berlangsung dengan kondusif.

\section{PENUTUP}

\section{Kesimpulan}

Adanya rencana penambangan pasir besi di wilayah Jepara Utara (Kecamatan Donorojo, Keling, Kembang, Bangsri dan Mlonggo) yang akan dilaksanakan oleh PT. Alam Mineral Lestari telah menimbulkan keresahan di masyarakat wilayah Jepara Utara khususnya masyarakat yang akan terkena dampak adanya penambangan pasir besi diantaranya:

1. Terjadinya abrasi pantai yang akan merugikan masyarakat nelayan (pesisir).

2. Adanya pengurangan lahan garapan petani.

3. Akan berdampak kepada kerusakan lingkungan akibat dari penambangan tersebut.

Dari pihak perusahaan yang telah memiliki ijin usaha penambangan akan mengalami kerugian apabila tidak operasional karena biaya yang dikeluarkan dalam rangka pengurusan ijin maupun sosialisasi tidak dapat kembali.

Keteguhan dari masyarakat pesisir Jepara Utara untuk menolak segala macam penambangan pasir besi, dapat terlihat dari pengrusakan yang dilakukan terhadap kantor CV. Guci Mas Nusantara.

Keinginan dari para pengusaha untuk melakukan penambangan karena telah memiliki ljin Usaha Penambangan (IUP) sebagai syarat untuk melakukan operasional.

Penyusunan dokumen Amdal tidak menyertakan Undang-undang No. 41 tahun 1999 tentang Kehutanan. Bahwa kawasan hutan yang diajukan perijinan pinjam pakai oleh PT Alam Mineral Lestari untuk lokasi tambang pasir besi merupakan Hutan Produksi Tetap, namun di dalam kawasan tersebut terdapat kawasan Hutan perlindungan Setempat (KPS) yang terletak di petak 130 a, 131 a, 132 a dan 132 b dimana lokasi tersebut ditentukan melalui Rencana Pengaturan Kelestarian hutan ( RPKH ) sesuai dengan Peraturan Pemerintah RI Nomor 72 tahun 2010 tentang Perusahaan Umum (Perum) Kehutanan Negara.

Dengan adanya fakta di atas, terdapat perbedaan pendapat dari Dinas Kehutanan Prov. Jateng dengan KPH Pati mengenai status kawasan hutan yang berada di lokasi pengajuan ijin pinjam pakai untuk kepentingan usaha, dimana dari Dinas Kehutanan Prov. Jateng mengatakan bahwa kawasan tersebut merupakan kawasan hutan produksi tetap berdasarkan lampiran peta SK Menhut 359/SKptII/2004 tanggal 01 Oktober 2004 sehingga lokasi tersebut dapat di pinjam pakaikan kepada PT. AML, sedangkan dari KPH Pati (Perhutani Jepara) menjelaskan bahwa lokasi tersebut merupakan kawasan perlindungan setempat (KPS) sesuai dengan peta RPKH (Rencana Pengaturan Kelestarian Hutan) jangka waktu tahun 2009 - 2018 pada peta 130 a, 131 a dan 132 a, namun keputusan pemberian 
rekomendasi tetap melalui Kadin Kehutanan Provinsi Jateng sebelum penerbitan ijin pinjam pakai lokasi hutan oleh Menteri Kehutanan RI.

Berdasarkan pemaparan mengenai hasil dan pembahasan diatas maka kesimpulan yang dapat diambil, antara lain:

1. Penolakan yang dilakukan masyarakat dengan adanya penambangan pasir besi di wilayahnya, karena akan sangat merugikan dari segi ekonomi, dimana mata pencaharian masyarakat secara umum adalah nelayan dan petani.

2. Pihak perusahaan penambang dalam melaksanakan sosialisasi tidak merata dan menyentuh semua lini masyarakat sehingga terjadi penolakan terhadap aktifitas penambangan yang akan dilakukan.

3. Walaupun pihak pengusaha telah memiliki ijin, namun apabila warga sekitar (pemilik lahan) tidak menyetujui, maka penambangan tidak dapat dilakukan.

4. Bahwa penundaan penambangan pasir besi yang akan dilakukan oleh PT. AML bukan merupakan kebijakan dari Kapolres Jepara, namun merupakan hasil keputusan dari rapat oleh Fokopinda Jepara dan stake holder yang terkai, dengan pertimbangan situasi kamtibmas yaitu adanya penolakan oleh sebagian besar masyarakat desa Bandungharjo terbukti dari kejadian pengrusakan terhadap penambang pasir besi CV. GMN.

\section{Saran}

Saran yang dapat diberikan untuk permasalahan yang terjadi, antara lain:

1. Perlunya mediasi dengan pihak-pihak terkait dan masyarakat untuk mencari solusi masalah penambangan pasir besi.

2. Perlunya sosialisai ulang terhadap masyarakat terutama warga yang menolak adanya penambangan pasir besi.

3. Perlunya membentuk tim independen untuk melakukan pengkajian terhadap amdal dan perijinan.

4. Perlunya klarifikasi ijin penambangan di kawasan Perhutani terutama petak $130 \mathrm{a}, 130 \mathrm{~b}, 131 \mathrm{a}$, 132 a dan 132 b RPH Durentumbang BKPH Gajahbiru KPH Pati turut Ds. Bandungharjo Kec. Donorojo Kab. Jepara.

\section{Daftar Pustaka}

Sugiono. 1998. Metode penelitian adminitratif. Bandung: Alfabeta.

Soemitro, Ronny Hanitijo. 1983 Metode Penelitian Hukum. Jakarta: Ghalia Indonesia.

Singaribun, Masri dkk. 1998. Metode Penelitian Survey. Jakarta: LP3ES.

Latief, H. Abdul . 2005. Hukum dan Peraturan Kebijaksanaan (Beleidsregel) pada Pemerintahan Daerah. Yogyakarta: UII Press.

Sadhana, Kridawati. 2010. Etika Birokrasi Dalam Pelayanana Publik. Malang: CV. Citra.

Ratminto. 2002. Pelayanan Kualitas Pelayanan Publik di Era Otonomi Daerah: Harapan Yang Belum Menjadi Kenyataan. Yogyakarta: Jurnal IImu Sosial dan IImu Politik, UGM.

Rianto, Adi, 2005. Metodologi Penelitian dan Hukum. Jakarta. Granit.

Soemitro, Ronny Hanitijo .1983. Metode Penelitian Hukum. Jakarta: Ghalia Indonesia.

Soetriono, SRD, Rita Hanafie, 2007. Filsafat Ilmu dan Metodologi Penelitian. Yogyakarta: CV Andi Offset 